Chapman University

Chapman University Digital Commons

ESI Publications

Economic Science Institute

2015

\title{
Humankind in Civilization's Extended Order: A Tragedy, The First Part
}

Bart J. Wilson

ChapmanUniversity, bjwilson@chapman.edu

Follow this and additional works at: http://digitalcommons.chapman.edu/esi_pubs

Part of the Economic Theory Commons, and the Other Economics Commons

\section{Recommended Citation}

Wilson, B.J. (2015). Humankind in civilization's extended order: A tragedy, the first part. Supreme Court Economic Review, 23(1). http://doi.org/10.1086/686471

This Article is brought to you for free and open access by the Economic Science Institute at Chapman University Digital Commons. It has been accepted for inclusion in ESI Publications by an authorized administrator of Chapman University Digital Commons. For more information, please contactlaughtin@chapman.edu. 


\section{Humankind in Civilization’s Extended Order: A Tragedy, The First Part}

Comments

This article was originally published in Supreme Court Economic Review, volume 23, in 2015. DOI: 10.1086/ 686471

\section{Copyright}

University of Chicago Press 


\section{Humankind in Civilization's Extended Order: A Tragedy, The First Part}

Bart J. Wilson*

This article is a short, scientific story of the labyrinthian human career, of humankind's place in the natural order of the world, and of the evolution of moral rules and rule following that make the extended order of civilization possible. Drawing upon work in anthropology, biology, and linguistics, I weave a science-based narrative of how Homo sapiens came to be the only primate to convert enemy aliens into trading friends. It is a Goethean story of the human condition that postulates the common origins of and modern tension between Pleistocene and Anthropocene morality. It is also a Hayekian story of human universals and the uniqueness of our species that explicates some necessary but not sufficient conditions for our prosperity.

Two souls, alas, are dwelling in my breast, The one wants to separate from the other.

Faust, J.W. von Goethe ${ }^{1}$

${ }^{*}$ Economic ScienceInstitute, ChapmanUniversity, contactinformation:bartwilson @gmail.com. This paper has benefited from comments and suggestions from participants at a conference "The Ends of Capitalism," sponsored by the Classical Liberal Institute at the New York University School of Law, on February 26-27, 2015. For valuable comments on earlier drafts, I sincerely thank Gus Gradinger, Taylor Jaworski, Erik Kimbrough, Jimmy Langner, Jan Osborn, Matt Ridley, Sarah Skwire, Vernon Smith, Anna Wierzbicka, Brianna Asmus, Sarah Brosnan, Zach Dutra, and Ryan Johnson.

${ }^{1}$ J.W. von Goethe, Faust (Author's literal translation).

(C) 2016 by the University of Chicago. All rights reserved. 978-0-226-16666-7/2016/0023-0003\$10.00 
No longer the end pursued but the rules observed make the action good or bad.

The Fatal Conceit, F.A. Hayek ${ }^{2}$

\section{PRELUDE ON OUR SPECIES}

Homo sapiens is the only species in the history of the planet to turn its principal "hostile force of nature," itself, into a friend. Homo sapiens is the only species in the history of the planet to deliberately extend its own average life expectancy and intentionally decrease its own rate of infant mortality. Homo sapiens is the only species in the history of the planet to actualize healthier and more comfortable lives for itself. Homo sapiens is a marvel. We . . . are a marvel.

If these facts are not sufficiently marvelous to shock the reader, then let's ponder why the facts aren't marvelous. Everyone lives in this dynamic teeming world, but to many these facts are not known. The 22 percent who live in extreme poverty do not know them because they do not live them. ${ }^{3}$ The day has yet to arrive when we can say that no one lives in poverty. But even of those who do live long lives peaceably and comfortably, not many know these facts well, or have known them for long. It was just in 1990 when 47 percent of the world lived in extreme poverty. ${ }^{4}$ In absolute terms and as a percentage of the world's population, more and more people are living longer, better lives.

Yet there is an uneasiness. However it may be that more and more people are escaping poverty, not everyone is escaping its gravity at the same speed. Those who left earlier are accelerating in their standard of living. Despite seeing nothing but exponential growth behind us in world GDP per capita, we doubt the entire species is being lifted out of poverty. We see nothing but decay in the relative altitudes achieved, and we see others as weighted down or worse, left behind. In the back of our minds there is fear, not wonder, about this liftoff from poverty. What if our species has cheated biology with stolen fuel? What if instead of being a marvel our species has created a monster, something more than human and something we cannot control.

Whether we are exceptional or have created a monstrous Adam of our labors, consider the place our species occupies in nature. Like

${ }^{2}$ F.A. Hayek, The Fatal Conceit 88 (Routledge 1998) (W.W. Bartley III, ed).

${ }^{3}$ United Nations, The Millennium Development Goals Report 2013 (June 2013), online at http://www.undp.org/content/dam/undp/library/MDG/english/mdg-report -2013-english.pdf (visited Oct 12, 2015).

${ }^{4}$ Id. 
all forms of life (animal, plant, fungus, protistan, and moneran) our genes monitor our physical growth, metabolism, and behavior. ${ }^{5}$ Genes provide continuity, and genes provide for change. Homo sapiens is no exception. Like most or all animals, we learn how to act in and react to our environment. Monarch butterflies east of the Rockies migrate north and south, except for the year-round residents of Florida who stay put for the good weather. By a process of trial and error, success reinforces and failure weakens patterns of action. Our movements may be probabilistic and individually unpredictable, but they are not completely random. If there is no moist matter to mudpuddle at a particular spot, a butterfly flutters away to find another, contingent, of course, upon the prevailing wind and whether an oriole is diving. Patterns of action that are loose and indeterminate make survival more likely. Predictably precise patterns make for easy targets and are maladaptive to incremental changes in the environment.

Like some birds, many mammals, and most primates, we hand down patterns of actions. Some of these actions include instilling in infants patterns that are not acquired by the genes of a parent. When conditioned patterns of actions are the results of training from teachers who were likewise habituated to this pattern by their earlier teachers, the individual has acquired a practice. While biologists use the term tradition to describe this additional mechanism for continuity and change, tradition, and to a lesser extent custom, connotes a concomitance of belief with a habitual way of acting that I wish to avoid at this point. Practices may reach their apogee in Homo sapiens when these practices bond with thinking and knowing to produce traditions, but we are not that different from brownheaded cowbirds, bottlenose dolphins, and white-faced capuchin monkeys in that we all learn practices from our mentors. ${ }^{6}$

Like all mammals, our sociality starts with the nursing tie between mother and young, which is consequently the source of mammalian clustering. ${ }^{7}$ All members of a mammalian cluster categorize each other. In the closest category no two individuals are treated exactly the same. These intimates deal with each other as individuals. You

${ }^{5}$ Except where noted, see Charles F. Hockett, Man's Place in Nature (McGrawHill 1973), and references therein for details on the likenesses of Homo sapiens to other species.

${ }^{6}$ Dorothy M. Fragaszy and Susan Perry, eds, The Biology of Traditions: Models and Evidence (Cambridge 2003).

${ }^{7}$ Only 10-20 percent of all mammals cluster beyond mere mating and the motheroffspring nutritional link. See Peter J. Jarman and Hans Kruuk, eds, Phylogeny and Social Organization in Mammals, in David B. Croft and Udo Ganslober, eds, Comparison of Marsupial and Placental Behavior 80-101 (Finlander Verlag 1996). 
might say they deal "personally" with each other, though conspecifically would be nonanthropomorphically more accurate. The mother may be the only member of a young mammal's inner circle, and this may change with age. In time litter mates may also be treated as individuals, but one need not be closely related to know an individual as an individual. Whether a large or small set, the defining characteristic of the closest members in a cluster is that they are known to each other as individuals.

Beyond this inner circle, however, individuals are indistinct; they are categorized into various groups and treated as all members of the group are treated-the same. Category membership need not be symmetrical. For example, on the pain of punishment all subordinates know the dominant adult male as an individual, but the dominant adult male may treat all subordinate males as merely members of the group of subordinates. In mammalian sociality then, there are the conspecifically known, whom we treat as individuals, and the conspecifically unknown, with whom our relations are stereotyped, that is, our patterns of actions and reactions are uniformly applied. The conspecifically unknown may be allies, part of the fit and proper background of the cluster, or they may be aliens, hostile and feared.

Like all mammals, we play. We play to learn, to prepare for eating, sleeping, and fighting as adults. We also play to have fun. One important difference between primates and other mammals is that primates have extended lifespans and consequently an extended childhood and adolescence. This means that primates play longer when young. Primates also continue to play as adults. When we are young at heart, as one says, we continue to learn and hence innovate in our actions. Play makes our inherently conservative patterns of actions more flexible while on the thin margin for survival.

Another defining characteristic of our order is that, as C.F. Hockett emphasizes, "[p]rimates enjoy physical proximity and bodily contact." ${ }^{1 / 8}$ We primates take pleasure in regularly being in each other's company. It feels good to be in the proximity of those we know, and when not in the presence of those we know, we desire to be. But more than that, primates have a good time together. Our pleasure is mutual, and our fun is mutual. The result of these differences with other mammals is that, as an order, "primates who know each other simply do more different things together."

Alien primates, on other hand, are an instant physical threat. One either fights an alien when equally fit for combat or withdraws when outnumbered or physically outmatched. Not surprisingly, primate clusters do not intermingle (though bonobos and some species of

\footnotetext{
${ }^{8}$ Hockett, Man's Place in Nature at 68 (cited in note 5).

${ }^{9}$ Id at 72 .
} 
baboons are an occasional exception). Out of necessity small vulnerable groups may merge and large clusters may subdivide, but almost never does an individual alien join a different cluster as a new fullfledged member. Membership of a primate cluster is largely for life.

Primate sociality is the most complex of the class. It balances our inner circle treatment of individuals as individuals with the mutual aid of the broader cluster against environmental threats. We are not individually large and formidable enough to withstand predators on our own and we don't play the numbers game of producing oodles of young so that just a few might survive. Primate sociality falls in between stoic individuality and mass anonymity. By interconnecting the individually known to the individually unknown, primate sociality is the foundation of community and has evolved for the perpetuance of the community. An individual qua an individual matters to those to whom we are known; that is the primate way. The community also matters, but not the community qua the community. The community of mutual aid is simply the complement of the set of aggressive aliens, a social formation that makes survival possible. Primate sociality is the source of our connatural, that is, unlearnt, feelings toward each other and hence, a big hence, the source of our moral sentiments.

We have enough comparative biology. The history of our sociality is deeper and more shared with the rest of the animal kingdom than we might pridefully think. In it also we see our fear of the fearless and therefore powerful alien. Combine this common history with symbolic thought and civilization and we will have the makings of restless, dissatisfied human beings. But I anticipate. The value of placing humankind in evolutionary context is not to pigeonhole our actions and to treat the patterns as constraints so given. Nor especially is it to be a moral guide. Rather, it is to situate humankind's lot, to move with thoughtful haste through time, from the Miocene through the Pleistocene to the Holocene now.

\section{PROLOGUE ON THE PLEISTOCENE PLAIN}

As humble and humbling as our genealogical relations may be, we are the small god of the world. We stand alone with a spark of heaven's light: symbolic thought. ${ }^{10}$ All chordate communication systems, except ours, are bound to the here and now. ${ }^{11}$ Only the human communication system can refer to a threat not physically present or a

${ }^{10}$ See Terrence W. Deacon, The Symbolic Species: The Co-evolution of Language and the Brain (Norton 1998).

${ }^{11}$ See Derek Bickerton, Adam's Tongue: How Humans Made Language, How Language Made Humans (Hill \& Wang 2009). 
food source beyond the hill. And only the human communication system exhibits symbolic relations among the signs.

Most primate calls can vary in frequency and loudness. ${ }^{12}$ The more frequent or louder is the danger call the more intense the state that elicited the sign. Hearers interpret this similarity between the sign and the intensity of the caller's state and respond accordingly. This "iconic" reference between the sign and what it refers to is old hat for primates. Other primate calls are "indexical," that is, they point in space and time to distinct threats right here, right now. A vervet monkey has a different call to alert the rest of the troop to the presence of either a leopard, an eagle, or a snake, each eliciting a different response: run up for a leopard, run down for an eagle, and look around for a snake. ${ }^{13}$ To be a primate as any primate is to interpret iconic and indexical signs.

The spark that defeats all other animals is symbolic thought. What was the selection pressure that ignited symbolic thinking in the genus Homo? Every species must adapt to the facts of its environment to survive. Two million years ago proto-humans began carving out a new ecological niche as scavengers. Derek Bickerton argues that the selection pressure to solve the recruitment problem could have been strong enough to produce the first proto-words. ${ }^{14}$ Words as symbolic signs exchange information displaced from what we can see before our very eyes. Conveying information about time (past, present, or future) and place (here, there, or anywhere) is a considerable advantage for coordinating a group of scavengers, especially when competing in a carnivorous world dominated by fangs and claws. Besides humans only bees and ants have achieved such displacement in communication. The difference with their recruitment is that waggle dances and pheromones are not symbolic. Our signs are.

The fundamental difference between indexical and symbolic communication systems is that indices are only supported by the strength of what is the case, whereas symbols are supported by both what is and what is not the case. Consider first how an indexical sign works. When a smoke detector goes off, the beep indicates the presence of smoke. If the microwave made the same beep as the smoke detector, then the strength of the smoke detector's beep as an indicator of

\footnotetext{
12 See William O. Dingwall, The Evolution of Human Communication Systems, in Haiganoosh Whitaker and Harry A. Whitaker, eds, 4 Studies in Neurolinguistics (Academic 1979).

${ }^{13}$ See Robert Seyfarth, Dorothy Cheney, and Peter Marler, eds, Monkey Responses to Three Different Alarm Calls: Evidence of Predator Classifications and Semantic Communication, 210 Sci 801 (1980).

${ }^{14}$ Bickerton, Adam's Tongue (cited in note 11).
} 
smoke is considerably weaker. An indexical sign is only as strong as the direct association that supports it.

Consider how the words eat and drink work as symbols. Why don't we drink M\&Ms or eat milk? Because a rule of the word eat is that the object it takes must not be a liquid. As a symbol eat conveys the meaning of chewing and swallowing, and, simultaneously, it does not convey the meaning of simply swallowing once taken into the mouth. Eat is supported by all of the symbols for edibles that are solid, as well as all of the symbols for potables that cannot be chewed before swallowing. Notice the openness of a symbolic system to the unforeseeable. If you were to encounter a completely foreign digestible called a rath, without any teaching you would know in a conversation whether you would say you "drink it" or "eat it" based upon whether it is a liquid or a solid.

Words then are linked to each other in an interlocking set of relationships governed by rules. And with words come concepts. Words that are free of time and place are free for, as Bickerton calls it, offline thinking. He carefully explains:

I'm not saying that "concepts are words," or "you have to have a word to have a concept." Least of all am I saying, "You can't think without words." . . The difference between online and offline thinking is . . . that in online thinking, what's being thought about is right there in front of you, while in offline thinking it isn't. . . . [O]ffline thinking . . . by definition [is] thinking about [what] can't be there. Only the concepts can be there. . . . Words are simply permanent anchors that most concepts have-a means of pulling together all the sights and sounds and smells, all the varied kinds of knowledge we have about what the concept refers to. But once the brain found the trick of making concepts, it no longer needed a word as the base for a new concept. It just needed some place where all the knowledge could come together and link with other concepts. ${ }^{15}$

Now imagine what a primate with a disposition toward play could do combinatorially with concepts not bound to the here and now. It could create things that do not exist, like devils or unicorns that poop rainbows. It could, as every human community does, polish language for poetic and artistic purposes, and it could, as every human community does, use language to construct a Weltanschauung. ${ }^{16}$ Playing with concepts is also serious business when survival hinges on successfully adapting to facts. Disappointment and doubt

${ }^{15}$ Id at 207-08.

${ }^{16}$ Donald E. Brown, Human Universals (McGraw-Hill 1991). 
about the environment when combined with mammalian playful curiosity yield a desire to search for the truth of reality, that is, it yields science. In every language ever studied people can express the concept/value TRUE. ${ }^{17}$

Once the pilot light of a symbolic mind was lit, categorical differences in kind become possible in our patterns of doing and thinking. Birds may build nests and beavers dams and lodges, but neither's construction projects require imagining what might be more useful or productive in the future. They simply do what is necessary to construct the artifact: Move tree matter from there to here and adhere with mud. In addition to producing artifacts, animals also use primary tools. Chimpanzees prepare sticks for extracting a snack from a termite hill and crush leaves into sponges for drinking water..$^{18}$ But only humans make and use tools to make and use derivative tools, and all humans do this. ${ }^{19}$ When no longer confined to the here and now, a little creative tinkering can transform something currently not useful or possible into something that might be in the future. Integrate this tinkering disposition into a practice, and know-how isn't simply passed on from generation to generation; it accumulates from generation to generation. And it accumulates in the dispersed minds of the community. With each successive generation human conspecifics become increasingly different, increasingly unequal.

If the symbolic mind supports two large discontinuities, language and creativity, between humans and nonhumans, ${ }^{20}$ why stop with just these two differences? When Matt Ridley observes that no other species is as innovative as humans, he explains it as an extension of a third large discontinuity: humans are the only animal to routinely exchange one thing for another thing. ${ }^{21}$ For two people to exchange for mutual benefit it is necessary for their minds to escape the here and now.

Suppose Adam has apples and $\mathrm{Oz}$ oranges. To voluntarily exchange their goods both must imagine a future state of the world in which Adam has oranges and $\mathrm{Oz}$ apples. That is, both must imagine that as Adam hands over the apples $\mathrm{Oz}$ hands over the oranges. Say that Adam chooses to move first, handing the apples over to Oz. Adam forgoes the apples in the here and now, holding in his mind several

\footnotetext{
${ }^{17}$ See Cliff Goddard and Anna Wierzbicka, Meaning and Universal Grammar: Theory and Empirical Findings 2 (Benjamins 2002). The same is not true for false.

${ }^{18}$ See Hockett, Man's Place in Nature (cited in note 5).

${ }^{19}$ Brown, Human Universal (cited in note 16); see also Anna Wierzbicka, Semantics: Primes and Universals (Oxford 1996).

${ }^{20}$ Bickerton, Adam's Tongue (cited in note 11).

${ }^{21}$ See Matt Ridley, The Rational Optimist: How Prosperity Evolves (Harper 2010).
} 
symbols of the present: (1) a future $\mathrm{Oz}(2)$ who hands over in the future (3) some future oranges (4) to a future himself. A future $\mathrm{Oz}$ is symbolic because it does not directly refer to the Oz standing before Adam. Yes, a future $\mathrm{Oz}$ points to $\mathrm{Oz}$, the person in the present. If it didn't there could be no symbol of a future Oz. But a symbol, like a future $\mathrm{Oz}$, conveys meaning $\mathrm{m}$ only in a context in which not $(\mathrm{m})$ could also occur but didn't. ${ }^{22}$ Every human community employs the logical notion of "not." 23

A future $\mathrm{Oz}$ conveys a meaning in the here and now because Adam could have chosen not to hand over the apples and instead, say, kill $\mathrm{Oz}$ and take his oranges. It is this tacit understanding of all the explicitly discarded information that is not the case that gives meaning to the symbol of a future $\mathrm{Oz}$ (and all the other symbols in the exchange).

Killing $\mathrm{Oz}$ is not a far-fetched alternative, as evidenced by the Greek for "to exchange," katallattein, which at one time also meant "to change from enemy into friend." ${ }^{4}$ So when Adam has the opportunity to not hand over apples in the here and now and he shows that that is not true, his action of handing over the apples supports the interlocking symbolic relationships of exchange. Given that

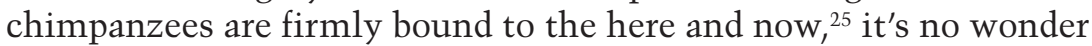
that they do not barter: ${ }^{26}$ they cannot entertain the counterfactuals necessary to support giving up something of lesser value to attain something of greater value. All human communities trade things. ${ }^{27}$

A fourth large discontinuity from other animals is that humans are moral beings, and without symbolic thought we could not be moral. At the core of morality is the abstract evaluation of what is good. The concept GOOD is atomic; that is, no other atomic concepts (also called "semantic primes") can define it and its indefinable except of itself. ${ }^{28}$ Some human communities contrast the term "good" with a term "not good" and others with a term for "bad." But no human community expresses the contrasting terms as "bad" and "not bad" with no term for "good." 29 Only with "good" and "bad" can "not bad" express an intermediate case. A word for GOoD

${ }^{22}$ Deacon, The Symbolic Species at 79-92 (cited in note 10).

${ }^{23}$ Brown, Human Universal (cited in note 16).

${ }^{24}$ See Friedrich A. Hayek, 2 Law, Legislation, and Liberty 108 (Chicago 1976).

${ }^{25}$ Deacon, The Symbolic Species (cited in note 10).

${ }^{26}$ See Sara F. Brosnan et al, Chimpanzee Autarky, 3 Plos One 1, (2008), online at http://journals.plos.org/plosone/article?id=10.1371/journal.pone.0001518.

${ }^{27}$ Brown, Human Universals (cited in note 16).

${ }^{28}$ Wierzbicka, Semantics (cited in note 19).

${ }^{29}$ Brown, Human Universals (cited in note 16). 
is universal and universally unmarked. ${ }^{30}$ Without any need for a definition, good means GOoD to every person in every language whatever the word for it is.

Doing good consists not in the good things we get to satisfy our most basic animalistic impulses to ingest, excrete, and avoid pain, heat, and cold. Doing good consists in the good direction of our motives which good things satisfy. ${ }^{31}$ To ascribe a motive as good, someone else's or one's own, requires the abstract concepts You and I. Dolphins, elephants, and nonhuman apes can recognize themselves in mirrors, ${ }^{32}$ which is a necessary condition for an " $\mathrm{I}$ " to understand "your" motives, but none can evaluate motives of others with the abstract concept of GOOD because GOOD stands outside the here and now. ${ }^{33}$ All human languages contain pronouns, ${ }^{34}$ and more specifically, pronouns for the abstract concepts You and I. ${ }^{35}$ Both YOU and I stand outside the present, the pronouns for which are symbols of someone who both has acted in the past and will act in the future.

Unlike a chimpanzee that can identify a self, for us symbolic thinkers there is not simply a self in the mirror because there is no self without other selves. There is an "I" in the mirror that we get to know by experience of the "We." " $\mathrm{I}$ " is not a trivial concept. It is the only concept which only I may use to refer to myself. No other

\footnotetext{
${ }^{30}$ Goddard and Wierzbicka, Meaning and Universal Grammar (cited in note 17), argue that BAD is also a universally distinct concept even though it is more readily expressed in some languages as NOT GOOD: Goddard and Wierzbicka, Meaning and Universal Grammar at 496-97 (cited at 17). If the word for BAD in another language, like Acehnese, connotes something stronger than bad does in English, then the contextual use of the word for BAD in Acehnese may less readily call for NOT GOOD as opposed to BAD.

31 "'Tis evident, that when we praise any actions, we regard only the motives that produc'd them, and consider the actions as signs or indications of certain principles in the mind and temper. The external performance has no merit. We must look within to find the moral quality." David Hume, A Treatise of Human Nature 307 ([1740] Oxford 2000) (David F. Norton and Mary J. Norton, eds).

${ }^{32}$ See Frans B.M. de Waal, Primates and Philosophers: How Morality Evolved (Princeton 2006).

${ }^{33}$ See Christopher Boehm, Moral Origins: The Evolution of Virtue, Altruism, and Shame (Basics 2012).

${ }^{34}$ Brown, Human Universals (cited in note 16).

${ }^{35}$ Wierzbicka, Semantics (cited in note 19 ).

${ }^{36}$ Compare with Adam Smith, Theory of Moral Sentiments 113 ([1759] Liberty Fund 1982): "Were it possible that a human creature could grow up to manhood in some solitary place, without any communication with his own species, he could no more think of his own character. . . Bring him into society, and he is immediately provided with the mirror which he wanted before." Once there is a "We," each "I" can imagine Adam Smith's impartial spectator.
} 
person uses the concept I to refer to me. The problem which morality solves is how all the individual I's in a community of "We" can fittingly satisfy their basic impulses while maintaining the primate pleasure of being in each other's company. ${ }^{37}$ We not only demand that others do good. We also care that we ourselves supply good conduct. Both the demand and supply of good conduct are a function of conceptualized motives. The outward action is the symbolic sign.

When this talking, trading, innovating, motive-ascribing little god of a hominid appears 150,000 to 50,000 years ago on the Pleistocene plain, it is living in bands with unique features. First, humans compete in groups more "extensively, fluidly, and complexly" than any other sexual organism. ${ }^{38}$ Unlike the mainly inbreeding bands of nonhuman primates, early human bands were exogamous. ${ }^{39}$ And with the exchange of women spread dispersed technical innovations in controlling fire and its applications to roasting and boiling food. ${ }^{40}$ Now why would a symbolic species go about exchanging women? Because, secondly, Homo sapiens is the only species to compete on a large scale group against group. ${ }^{41}$ Unlike any other species, other humans were the primary reason why early humans did not survive or reproduce. ${ }^{42}$ Humans are one of three species that deliberately and frequently kill conspecifics over territory. ${ }^{43}$ The other two are chimpanzees and wolves, which are also groupish and highly social. But only in humans did kinship ties from exogamy ever so slightly decrease the frequency of intergroup violence. Early Homo sapiens, though, was not done converting enemies into friends. Their enemiesturned-friends were conspecifically, no, personally, known to each other, being just down the road. Modern Homo sapiens takes exchange much further, converting the personally unknown from enemies into honorary friends. But I divulge too soon.

To protect themselves against external threats other gregarious species flock, herd, or school to form large groups of anonymous masses. When the principal threat is within the same species, the

${ }^{37}$ Id at 116: "Nature, when she formed man for society, endowed him with an original desire to please, and an original aversion to offend his brethren. She taught him to feel pleasure in their favourable, and pain in their unfavourable regard. She rendered their approbation most flattering and most agreeable to him for its own sake; and their disapprobation most mortifying and most offensive."

${ }^{38}$ See Richard D. Alexander, The Biology of Moral Systems 80 (Aldine 1987).

${ }^{39}$ Hockett, Man's Place in Nature (cited in note 5).

${ }^{40}$ See Chester S. Chard, Man in Prehistory (McGraw-Hill 1969), in Hockett, Man's Place in Nature (cited in note 5).

${ }^{41}$ See Alexander, The Biology of Moral Systems (cited in note 38).

${ }^{42}$ Id at 80.

${ }^{43}$ See Richard Wrangham, Killer Species, 133 Daedalus 25 (2004). 
between-group aggression formatively begets the unlearnt feelings for living within the group. Larger groups create more potential conflicts of interest, that is, greater costs of living within the group. Thus, to minimize these costs the unlearnt feelings selected for living within the group were constitutive of common purposes and common ends. If there was no between-group aggression, instincts of solidarity would not have been necessary. The unlearnt feelings that support between-group aggression can be glossed as enmity, ill will, and hate for those outside the "We" and amity, goodwill, and love for the members of the "We."

Mutualism governs the relations of an "I" in the "We." ${ }^{14}$ People participate in a war party with other people in the group because they think that people want to be successful in the raid, that each "I" wants the same thing. The people in the group also think that success in the raid will be good for everyone in the group, and each "I" thinks that it will be good for "me" too. The war party, however, will not be successful if some people don't do their part. Because of this, each "I" wants to do his part in the war party. Each "I" does his part not because he is restrained by the "We" to do so, but because he socializes his own conduct to be able to live in the "We." ${ }^{\prime 45}$

The most distinctive feature of the "We" in early human groups is their egalitarianism. ${ }^{46}$ The social structures of our most closely related primates are hierarchical. Christopher Boehm hypothesizes that the selection pressure from large-game hunting transformed what must have been hierarchical groups of hominids in the Miocene into egalitarian groups in the Pleistocene. This evolution requires dispositions to control upstart dominants, incorrigible deviants, and sneaky free-riders. As an example of the problems egalitarian groups face, Boehm recounts Colin Turnbull's story of Cephu, a Mbuti Pygmy from the Congo region of Africa. On the day of the recounted incident Cephu's band went hunting for forest antelope. Unlike large-game hunting, which men carry out with projectile weapons, this hunting expedition was for small game and involved the entire group. The men would set up large nets in a semicircle

\footnotetext{
${ }^{44}$ See Anna Wierzbicka, Imprisoned in English: The Hazards of English as a Default Language 111 (Oxford 2014); see also Michael Tomasello, Why We Cooperate (MIT 2009).

${ }^{45}$ Smith, Theory of Moral Sentiments at 182 (cited in note 36): "When he views himself in the light in which he is conscious that others will view him, he sees that to them he is but one of the multitude in no respect better than any other in it. If he would act so as that the impartial spectator may enter into the principles of his conduct, which is what of all things he has the greatest desire to do, he must, upon this, as upon all other occasions, humble the arrogance of his self-love, and bring it down to something which other men can go along with."

${ }^{46}$ Boehm, Moral Origins (cited in note 33).
} 
and the women and children would noisily drive the prey toward the traps. Each man would spear the prey in his net and feed his family with it.

If every man set up his net in the large semicircle, no redistribution would be required. Every net would catch something. Cephu, however, decided that he would improve his chances by moving his net ahead of everyone else's. He didn't think anyone saw him in the dense forest. Cephu was wrong. Upon returning to the main camp, the other men relentlessly hurled insults at him. He was even denied a chair by a mere youth. Cephu tried to cover up his deviousness with the lie that he had lost the group in the forest, but the band would hear nothing of it. They knew what had happened and he knew that they knew what had happened. Cephu eventually broke down with an apology and an offer to hand over the meat. The band seized it all, including a liver that his wife had hidden in anticipation of just such an eventuality. With that reparation, Cephu was again an accepted member of the band.

Apart from his close family, the band was united against Cephu. The group shared rules of conduct and had agreed on the facts, the significance of which Boehm explains: "[t]his singularity of purpose is important because if a consensus is not built before action is taken, what might otherwise have been an instance of efficient group sanctioning can turn into sheer factional conflict, with both sides claiming moral rectitude," and so on and so on as in the Hatfields and the McCoys. ${ }^{47}$ Like Boehm, Alexander emphasizes that groups maintain cohesion with rules that serve as "restraints on particular methods of seeking self-interests, specifically on activities that affect deleteriously the efforts of others to seek their own interests." ${ }^{\prime 8}$ Such are the demands of morality upon our conduct. But why did everyone else in Cephu's band not defect? Was it solely out of a fear for being treated like Cephu, or have humans, as Dennis Krebs posits, "acquired the disposition to obey rules when no one is watching"? ${ }^{49}$ The band apart from Cephu supplied good conduct because each "I" of the group thought it would be good for the group and good for each "me." Each " $\mathrm{I}$ " in the group, as Lionel Tiger and Robin Fox explain, "is not so much closely connected with the product of his own labor as he is with the product of the joint labors of his group, in a direct and satisfying way." 50

${ }^{47}$ Id at 244.

${ }^{48}$ Richard D. Alexander, The Biology of Moral Systems 80, 81 (Aldine 1987).

${ }^{49}$ Krebs appears unaware that he is channeling Adam Smith via his Darwininspired project. See Dennis L. Krebs, The Origins of Morality 84 (Oxford 2011).

${ }^{50}$ See Lionel Tiger and Robin Fox, The Imperial Animal 132 (Holt, Rinehart \& Winston 1971). 
Cephu was not the first nor was he the last of his band to seek more and better. But no member of any other species could act as he did with the purpose of achieving more in the future. Along with GOOD and BAD, NOT and TRUE, and YOU and I, WANT and MORE are also universal human concepts that stand outside the here and now. ${ }^{51}$ To want more and to want better is to be human. "A million years of natural selection," says Ridley, "shaped human nature... not to settle for contentment: people are programmed to desire, not to appreciate. ${ }^{\prime 52}$ That is not to say that after all that time we want more and better with clarity. We may, like Cephu, confusedly seek to satisfy the restlessness in our breast. Humankind errs as long we strive. Good people in their dark impulses, though, are well aware of the proper course.

We now turn to business.

\section{THE FIRST PART OF THE TRAGEDY}

On the eve of civilization human bands lived in egalitarian Gardens of Eden. The boundaries between these Edens were, lest we with rose-tinted nostalgia forget, bloody and deadly. ${ }^{53}$ But inside each Eden what universal sentiment ennobled humankind with the ideal of equality? The usual story, as I have already stated, rests on the selection pressure to make group hunting of large game efficacious. The usual presentation of the story, as Boehm exemplifies, begins by contrasting actions that support and hinder the pursuit of large game. There are those actions that must be good, such as "sharing" the product of the hunt "equally," and those that must be bad, such as "bullying," "cheating," and "thieving" others out of "their shares." ${ }^{54}$ It is easy to read our own modern valuations into the problem, as I did above when I summarized the problem as "control[ling] upstart dominants, incorrigible deviants, and sneaky free-riders." Attaching the value judgment of BAD to actions that are "punished" for not supporting efficacious large game hunting, however, is insufficient to begin answering our question on the origins of our egalitarianism, for it fallaciously assumes as a conclusion that which we wish to explain. The problem is often posed as what are the evolutionary origins of the mental structure called a conscience, "a mechanism that induces people to pass judgment on themselves

\footnotetext{
${ }^{51}$ Wierzbicka, Semantics 76-78 (cited in note 19).

${ }^{52}$ Ridley, The Rational Optimist at 27 (cited in note 21).

${ }^{53}$ See Steven Pinker, The Better Angels of Our Nature: Why Violence Has Declined (Penguin 2012).

${ }^{54}$ Boehm, Moral Origins at 152 (cited in note 33).
} 
and their behaviors."55 But as Adam Smith astutely recognized, "[t] he word conscience does not immediately denote any moral faculty by which we approve or disapprove. Conscience supposes, indeed, the existence of some such faculty, and properly signifies our consciousness of having acted agreeably or contrary to its directions. ${ }^{\prime 56}$ The question of how we think and feel about the equality and inequality of ends remains. We need an amoral sentiment to jumpstart a moralizing tradition.

Suppose Cephu finds success on a large game hunt but his fellow hunters are not so fortunate. To assume that Cephu has evolved a conscience that approves of sharing the hunt equally and disapproves of bullying others out of their shares raises the question why Cephu cares about a sharing norm and equality. It also begs the question of why the rest of the band cares about equality. So let's first consider what the unsuccessful families think and feel. ${ }^{57}$ Upon Cephu's return to camp, the other hunters and their families think to themselves that something good has happened to Cephu and that it didn't happen to them. Moreover, it is bad for them that their hunter returned without anything, for they have no food. They want good things like a successful hunt to happen to them. When they think about Cephu's success and their hunter's lack thereof, they are reminded that they are without food and they feel bad.

What will hungry people who feel bad do if they remain hungry? They will take the food from Cephu. If Cephu fears that his band will take food from him and potentially leave him and his family without any, what will Cephu do? He will give portions to the other families to make them feel better. A tiny, $\varepsilon>0$ portion will not suffice because the families will still feel bad. How far will Cephu go in doling out portions? From his prior experience Cephu knows that, despite his finely honed hunting skills, sometimes the prey won't cross his path. Cephu knows that sometime in the future he will be in the same position as the other families, thinking and feeling like they think and feel now. Knowing how large game hunting works and empathizing with the other families, Cephu gives each family the same portion he gives his own.

If Cephu and his band pass this pattern of action down to their sons, and their sons to their sons, and so on and so on, then the band

\footnotetext{
${ }^{55}$ Krebs, The Origins of Morality at 207 (cited in note 49). See also Boehm, Moral Origins at 152 (cited in note 33).

${ }^{56}$ Smith, Theory of Moral Sentiments at 326 (cited in note 36).

${ }^{57}$ In addition to WANT, Wierzbicka, Semantics (cited in note 19), identifies three other atomistic mental predicates that are universally found in human languages: THINK, FEEL, and KNOW.
} 
follows the practice of sharing the hunt. Because this practice of sharing has survival value, the practice gradually gives rise to what we call memory and foresight, that is, a belief outside the here and now that pursuing the end of sharing is good. ${ }^{58}$ Integrate this belief into the verbal play of communicating this value to each other and we have more than the practice of a dolphin or a monkey; we have tradition.

Our question remains unanswered: What is the universal sentiment that ennobled humankind with the ideal of equality? It is the same sentiment that L.P. Hartley's dystopia obsessively fears in Facial Justice and the same sentiment that depraves Melville's Claggart, wracks Shelley's monster, spurs Shakespeare's Iago, and consumes Milton's Satan. That sentiment is envy.

Envy is a universal human sentiment, and every human community symbolically copes with the fear of envy. ${ }^{59}$ But how can the principle of-in your most mellifluous French-égalité be founded upon so odious a sentiment as envie? Surely, we exclaim with a tinge of indignation, the Good " $\mathrm{E}$ " cannot be founded upon the Bad "E." We are more willing, perhaps, to admit that our desire for equality is founded upon empathizing with the gratefulness of those who benefit from reducing inequality. Gratefulness and envy, however, are counterparts to one another: If our desire for equality arises from empathizing with the gratefulness of the less equal who would become more equal with sharing, our fear of and antipathy for inequality can hardly fail to proceed from empathizing with the envy of the less equal.

Envy is connatural. No one has to teach us how to envy another person. We simply think and feel the desire to acquire something possessed by another person. We do, however, have to be taught, via tradition, how to keep a check on our envy.

Envy is ubiquitous. The anthropologist George Foster collects examples from around the globe and across history of three of the most common envy-causing items: food, children, and health..$^{60}$ Not surprisingly, all three comprise the core of a family's survival. Customs around each item have sprung up as controls on the fear of the envy. For example, to avoid piercing eyes of envy, the Spanish in the village of Yegen would sit in the corner and eat with their backs

\footnotetext{
${ }^{58}$ This is what Hayek means when he says that reason "logically, psychologically, and temporally" follows from tradition, that is, "[m]an is not born wise, rational, and good, but has to be taught to become so." Hayek, The Fatal Conceit at 21, 23 (cited in note 2).

${ }^{59}$ See George F. Foster, The Anatomy of Envy: A Study in Symbolic Behavior, 13 Current Anthropology 165 (1972).

${ }^{60}$ Foster, The Anatomy of Envy 13 Current Anthropology 165.
} 
to the room. ${ }^{61}$ From Egypt to India and Taiwan families would give children denigrating names, like Small Snake or Pot, so as to symbolically deny there is a reason to envy them. ${ }^{62}$

The etymology of envy provides a clue that points to further evidence of the pervasiveness of envy in human history. Envy comes from the Latin invidia, which itself is the nominalization of invidere: to look askance or maliciously upon, or to cast an evil eye upon. ${ }^{63}$ The evil eye is the eye of the envious person. "From time immemorial," expounds the sociologist Helmut Schoeck, "suspicion of witchcraft or black magic has fallen upon those who have had cause to be envious-of someone less ugly than themselves, of lucky parents, or the peasant with a good harvest and healthy cattle, etc. . . . It is a constant aspect of primitive existence. Some tribes, such as the Navaho of North America, the African Azande and the West Pacific islanders, the Dobuans, seem to have a particularly strong belief in witchcraft, but basically the picture is the same wherever the investigation is made." ${ }^{\prime 64}$ Envy is at the very heart of such charming children's stories as Cinderella. Supernatural witches are always ugly in modern fairy tales so that they have a believable motivation to harm the innocent protagonist. Schoeck also provides example after example of the connection between black magic and those whose circumstances are envied: "A bright child who matures early is regarded by the Lovedu as a future witch. Life is spent in perpetual fear of envy." ${ }^{\prime 65}$ It is perhaps more useful for understanding Pleistocene morality to describe early bands of Homo sapiens, not as noble sounding egalitarians, but rather as invidiosi, envious people.

Envy is taboo. Try attributing it to someone in everyday conversation and see how well that goes over. Or try finding envy as a human motive in social science research or literary criticism. It's there, but not easily found. For decades worth of volumes in the mid-twentieth century Schoeck finds not one single instance of the word in the subject index of major anthropology and sociology journals. Not one. He also identifies a "blind spot" toward the envy-motive in several scholarly discussions of Melville's Billy Budd, Sailor, ${ }^{66}$ this despite chapter twelve's title, "Pale ire, envy and despair" (Milton's

${ }^{61}$ Id at 180.

${ }^{62}$ Id at $176-77$.

${ }^{63}$ See the entry for invideo, online at http://en.wiktionary.org/wiki/invideo\#Latin (last visited Oct 15, 2015).

${ }^{64}$ See Helmut Schoeck, Envy: A Theory of Social Behaviour 40 (Liberty Fund repr 1987).

${ }^{65} \mathrm{Id}$ at 50 .

${ }^{66}$ Id at $168-71$. 
description of Satan sans the comma after "pale" $\mid{ }^{67}$ The unwillingness to acknowledge envy at work in human intercourse continues to this day. The Wikipedia page for Melville's novella is devoid of any words beginning with "env." 68 As Foster says, "[i]t is probably because of the enormous hold that envy has on us, and a measure of the inner depths to which it stirs us, that we are reluctant to admit to envy, and to discuss it openly ..." 1169

Envy is destructive. Left unchecked it can quickly lead to hate and hate to violence, tearing asunder the ties that bind a group. Any band that does not control envy will not remain a band for very long. Envy also feeds our tigerish thirst to exterminate our enemies. It is not accidental that Milton, after living through a decade of three English civil wars, endows evil incarnate with envy.

Yet envy is a sentiment so unavoidable and so deeply implanted in the human condition that it would be unwise for any scientific inquiry into the sentiment to postulate that its ends are exclusively negative. Nor does it necessarily entail a moral judgment to call early Homo sapiens (and hence ourselves) invidiosi. As Nietzsche reads the Greeks of antiquity, envy also "spurs men to activity: not to the activity of fights of annihilation but to the activity of fights which are contests." ${ }^{\prime 70}$ Humankind's activity can easily abate; we prefer unconditional rest. Envy roils us from inactivity and passive acceptance of our current lot to contest, to achieve, to be a better hunter, sewer, storyteller, toolmaker, healer, or cook. The activity of a contest frees the mind from the grasp of invidious comparisons. With an "I'll-show-them" attitude, channeled toward positive achievement rather than destruction, the desire to overcome envy creates good. ${ }^{71}$ Envy, as Mephistopheles says of himself, is "Part of that force which would / Do evil evermore, and yet creates the good. ${ }^{\prime \prime 2}$

The black mist has now crept low into the garden. Adams and Eves divide their labor as they have been doing for quite some time. ${ }^{73}$ Allies through exogamy also engage in reciprocal gift giving trade.

\footnotetext{
${ }^{67}$ Melville's Billy Budd, Sailor (Simon \& Schuster 2006). The novella was published posthumously based upon notes. Because later versions drop the title for chapter 12, see an early version of the book entitled, Billy Budd, Foretopman.

${ }^{68}$ Billy Budd, online at http://en.wikipedia.org/wiki/Billy_Budd (visited on Oct 15, 2015).

${ }^{69}$ Foster, The Anatomy of Envy 13 Current Anthropology 165.

${ }^{70}$ See Friedrich Nietzsche, From Homer's Contest, in The Portable Nietzsche 35 ([1872] Viking Penguin 1954) (Walter Kaufmann, ed, trans).

${ }^{71}$ Schoeck, Envy at 415-17 (cited in note 64).

${ }^{72}$ See Johann Wolfgang von Goethe, Faust 159 (Anchor Books 1963) (Walter Kaufmann, trans).

${ }^{73}$ Ridley, The Rational Optimist (cited in note 21).
} 
Examples that have survived in present stateless societies include the ceremonial potlatch, kula, moka, and abutu. ${ }^{74}$ The symbols in gift exchange, such as the kula bracelets in the Trobriands, convey the meaning of goodwill and peace between groups, as well simultaneously not conveying the meaning of ill will and war. Indeed, failure to repay the gift exchange is "an act of hostility, a declaration that killing may now commence between the two groups. ${ }^{175}$ The consequent peace between gardens supports exchange in ordinary goods and the use of natural resources, such a fishing in a host's waters or quarrying for stone in the host's territory. ${ }^{76}$

All exchanges of ordinary goods are between personally known individuals, eyeball-to-eyeball. What everyone knows regarding the trade is what everyone sees, and what everyone sees is readily intelligible. Adam knows that the fish he cannot obtain locally is found in Oz's Eden. Oz also knows that the salt he wants is found in Adam's Eden. More than that, each knows that they each mixed their own labor with the items to be exchanged. From beginning to end Adam and $\mathrm{Oz}$ easily comprehend the production and distribution process. It's possible that $\mathrm{Oz}$ could personally secure salt for himself. It may be even closer than where Adam gets his, but certainly not closer than right here, right now. The exchange saves $\mathrm{Oz}$ precious time, and saved time in good times means marginal comfort and saved time in bad times means survival. When Adam and $\mathrm{Oz}$ exchange, each " $\mathrm{I}$ " thinks that it would be good for " $\mathrm{me}$ " and for the other " $\mathrm{I}$," and so, unlike with war parties and large game hunting, each " $\mathrm{I}$ " is becoming more closely connected with the product of his own labor than he is with the product of their joint labor, because there is no joint labor. There is interband trade in which all ends pursued are known to be good, in a direct and satisfying way.

The serpent continues his temptation for a better life. By 12,0009600 BC people in the Levant are living in widespread permanent settlements exchanging for obsidian from central Turkey and black basalt and seashells from the Mediterranean. ${ }^{77}$ Moving rapidly toward a fully domesticated mode of subsistence, people by 9600-6900 BC are widely cultivating and harvesting cereals and raising goats, sheep, pigs, and cattle. ${ }^{78}$ The cauldron of civilization, the Mesopotamian alluvium circa $6,500-3,800 \mathrm{BC}$, appears at first thought to

${ }^{74}$ See George Dalton, Aboriginal Economies in Stateless Societies, in Timothy K. Earle and Jonathon E. Ericson, eds, Exchange Systems in Prehistory 191 (Academic 1977).

${ }^{75}$ Id.

${ }^{76}$ Id.

${ }_{77}$ See Barry Cunliffe, Europe between the Oceans: 9000 BC-AD 1000, 91 (Yale 2008).

${ }^{78}$ Id at 91. 
contain few resources and only one ingredient, grain. But a closer look in the pot reveals three other zones of specialized subsistence, all linked by exchange networks. ${ }^{79}$ Semiarid pasturelands support full-time herdsman. Orchards and gardens near permanent rivers and streams provide summer harvests. Swamps and watercourses supply fish, a major source of protein, and reeds, a local building material.

Suppose, for example, that a Cephu lives in protoliterate southern Mesopotamia, sometime in the fourth millennium BC. His personal circumstances are particularly unfavorable, meaning he is an orphan, illegitimate son, halfbreed, or some other general outcast. ${ }^{80}$ Part of the fit and proper background, Cephu lives on the far edge of the settlement, known locally as Daisy, for its rolling hills of flowers where the sheep graze. Compared to the rest of residents of Daisy, Cephu is destitute, owning virtually nothing. ${ }^{81}$ Compared to 78 percent of us moderns, the residents of Daisy are destitute, living on the modern equivalent of $\$ 1.25$ a day, on a very good day. In Daisy there are the "have-nots" and the "care-nots." 82

Most of the residents of Daisy think, feel, and act, in harmony with the age old customs attached to the different subcommunities of herders, cereal cultivators, fishermen, and textile makers. Specialized know-how is passed down from parents to children, generation after generation. Insights from a little tinkering here and there accumulate in the dispersed minds of Daisy. Herders teach their children how to care for ewes having a difficult birth. Cultivators teach their children how to identify nonshattering spikes, an indicator of an easier harvest, in barley grasses. Eventually the wild barley is genetically modified, domesticated barley and only the recessive condition of nonshattering spikes is expressed. Children learn from their parents the customary rates for exchanging wool for reeds, dates for grain, fish for stone, and so forth. When under attack from roving bandits, the residents of Daisy defend each other against aggressors. The care-nots do not question the good and true values represented by the community. It is their simple acceptance of them which give Daisy's existence its uncomplicated naturalness. This is what

${ }^{79}$ See Robert McC Adams, The Evolution of Urban Society: Early Mesopotamia and Prehistoric Mexico 48 (Aldine 1966).

${ }^{80}$ Schoeck, Envy at 402 (cited in note 64).

${ }^{81}$ Cephu may own nothing, but all human groups have property in "tools, utensils, ornaments, and so forth." Ralph Linton, Universal Ethical Principles: An Anthropological View, in Ruth Nanda Anshen, ed, Moral Principles of Action: Man's Ethical Imperative 655 (Harper 1952).

${ }^{82}$ See Homer G. Barnett, Innovations: The Basis of Cultural Change 400 (McGrawHill 1953). 
"We" do and how "We" do it. Experience supplies what understanding cannot.

Cephu is a have-not invidioso. Every custom in Daisy chafes him. Not resigned to his fate, he seeks more and better than the grim existence of sub-subsistence. With nothing but a willingness to work long hours and a propensity to save, generic attributes of middleman minorities, ${ }^{83}$ Cephu peddles together some woolen textiles, dates, and dried fish and sets out for the far great North-Anatolia, Iran, or Syria - which he and everyone else in Daisy has only heard about in stories. In doing so, a have-not invidioso, thinking outside the here and now, breaks free from the Miocenian-old fear of aliens. With less to lose than a care-not, Cephu can attempt a risky change. Against the odds of being killed on the way, and not being killed upon arrival, he offers an Anatolian named Yahya (similarly on the fringe of his community) what little he has left in his cheap pack. In exchange Cephu receives tiny samples of dear things heard of but never before seen in Daisy: cedar and cypress oils (a bactericide, pesticide, and base for paints), common metals like bitumen and copper, and exotic metals like gold, silver, and lead. ${ }^{84}$

And so a southern Mesopotamian and an Anatolian initiate a very slow and gradual process of connecting two very different communities through trade, very slow and gradual because the mutual aliens must find novel ground rules for forming their new linking cluster. The novelty lies not in the manifest fact that human conspecifics have never shared common rules of conduct with regard to each other. Every human cluster maintains cohesion in the face of groupagainst-group competition with traditions that prescribe good ends and proscribe bad ends. The key proviso is that the "ethical systems function only in terms of in-groups," that is, they only apply to each "I" in the personally known "We." ${ }^{85}$ Aliens outside the "We" are not treated like the "We" are treated; they are simply another element of the natural world, like in this anecdote recounted by anthropologist Ralph Linton:

[T]he Maori of New Zealand, one of the most ingenious and philosophical of Stone Age peoples, showed all the virtues admired by Europeans in dealings with fellow tribesmen. Their attitude toward outsiders can be judged by the following: "A Maori relating an account of an expedition said incidentally, 'On the way I was speaking to a red-haired girl who had just

${ }^{83}$ See Thomas Sowell, Black Rednecks and White Liberals 65-110 (Encounter Books 2005).

${ }^{84}$ See Guillermo Algaze, The Uruk World System: The Dynamics of Expansion of Early Mesopotamian Civilization (Chicago 2005).

${ }^{85}$ Linton, Universal Ethical Principles at 649 (cited in note 81). 
been caught out in the open. . . My companions remained with the girl while I went on .... As we came back, I saw the head of the red-haired girl lying in the fern by the side of the track, and further on, we overtook one of the Waihou carrying a back load of flesh, which he was taking to our camp to be cooked for food; the arms of the girl were round his neck whilst the body was on his back.' ${ }^{\prime \prime 86}$

In contrast, the novelty is that through trade each alien conspecific becomes an honorary member of each other's "We," an entirely new category in the history of primate sociality-an enemy-alien becomes a friend. The category is new because honorary members are not full-fledged members of the original cluster; they remain aliens from another cluster, not personally known, not personally loved or cherished. In the museum of our mind there are no exhibits on the concrete ends of people we do not personally know. Mutually unknown circumstances and histories make it difficult to pursue good common ends. ${ }^{87}$ What is much less difficult and what honorary members are afforded is that "I" do not do bad things to (an honorary) "you." Each "I" evaluates "my" and "your" conduct in a common framework of general abstract rules that "largely consist of prohibitions ("shalt not's") that designate adjustable domains for individual decisions." ${ }^{\prime \prime 8}$

Notice the subtle shift. With members of the full-fledged "We," I refrain from doing things that will end up bad for you and you and you because I know what is individually bad for each different you. I personally know you and treat you as an individual. Each person can be treated differently because I know each one of you as an individual. Making a joke about someone's appearance works for some but not others because I know who can take it and who can't. Hence, "Do not joke about someone's appearance" is not a general, nor abstract rule. It is a person-by-person rule for people that I know. In contrast, because I do not personally know an honorary "you" as an individual, the proscriptions are more abstract: for example, do not steal, do not deceive, and do not breach a promise. ${ }^{89}$ The rules are abstract in that any honorary member $X$ can be inserted in the rule "Do not steal from $X .{ }^{190}$ Every honorary member of the "We" is treated the same.

\footnotetext{
${ }^{86}$ Id at 649-50.

${ }^{87}$ Hayek, The Fatal Conceit (cited in note 2).

${ }^{88}$ Id at 12 .

${ }^{89} \mathrm{Id}$.

${ }^{90}$ Of course, all general abstract rules also apply to full-fledged members of the "We," but they apply personally by virtue of the membership in the "We."
} 
The story now must change to tragedy and alienation, distance and distaste, anger and rebuke, foul distrust and disloyal breach. Suppose Cephu finds success on subsequent trips to and from Anatolia. He serves as the middleman exchanging Daisy's grain and woolen textiles with Yahya for cedar oil, bitumen, copper, and lead. What do Daisians think and feel about this business? Upon Cephu's return, the residents of Daisy think to themselves that something good has happened to Cephu and that it didn't happen to them. Moreover, it is bad for some of them; Anatolian metals are high quality substitutes for local building materials. The customary rates of exchange for stones are no longer customary; they are becoming more and more unfavorable each day. The stone quarriers are working the same or even more hours and receiving less grain, dates, and fish for each finished tool..$^{91}$ For many things, stones are becoming obsolete. The quarriers want good things like Cephu's prosperity to happen to them..$^{92}$ When they think about Cephu's success and their deteriorating standard of living, they feel bad.

Unlike with interband trade, this process is unintelligible to Daisians. When a Daisian exchanges with Cephu, each " $\mathrm{I}$ " is becoming even more closely connected with the product of his own labor. But, more important, each " $\mathrm{I}$ " is now disconnected from both the Anatolian labor that created the new product and the middleman's service that brought the product to their settlement. The production and distribution process transcends individual perception. Daisians cannot see and therefore do not know that their exchanges with Cephu are good for Anatolians. They cannot see the new rules of conduct that have changed enemy aliens into honorary friends. The ends pursued are unknown, in an indirect and rather unsatisfying way.

Some Daisians go further. They hurl insults at Cephu. They liken him in stories to a monster. They claim evil became his good. They say his success "stinks of sorcery." ${ }^{\prime 93} \mathrm{He}$ made nothing. He built nothing. He grew nothing. He herded nothing. And yet he created consumable riches out of woolen rags by buying cheap and selling dear. Cephu's success, indeed, doubly stinks of sorcery.

Pishery-pashery, maybe. Surely mistaken on all sorts of facts. But my point is how easy it is to envisage a role for envy at the birth of civilization that is both positive and negative, productive and destructive, value-affirming and value-denying, value-appreciating

${ }^{91}$ Hence, as Hayek says, "[c]onstraints on the practices of the small group, it must be emphasized and repeated, are hated." Hayek, The Fatal Conceit 13 (cited in note 2).

92 The rates of return from long-distance trade would be unfathomable, multiple hundreds of percent, or it might all be lost to roving bandits.

${ }_{93}$ Hayek, The Fatal Conceit at 91 (cited in note 2). 
and value-depreciating. The paragraph above on Cephu's success, like the corresponding one on Cephu's successful large game hunt, is built from Wierzbicka's definitional decomposition of envy. ${ }^{94}$ Envy itself is an amoral sentiment. How we act on envy and the fear of envy is a matter of morality.

As a precursor of the modern firm, Daisy, like all communities, was "a temporary aggregation of people to help them do their producing in such a way to help others do their consuming. ${ }^{\prime \prime 5}$ The trade links, made possible by new rules of conduct between honorary friends, combined with the zones of specialization to set off a chain reaction in the crucible of southern Mesopotamia. Seeking more and better people begin emptying the hillsides to form the first urban areas of Uruk. ${ }^{96}$ The stage is now set for the first extended order of civilization: "[T]he greater density of population, leading to the discovery of opportunities for specialization . . . led to yet further increases of population and per capita income that made possible another increase in the population. And so on. ${ }^{\prime \prime 97}$ The amity, goodwill, and love of the residents of Daisy for each other could not rescue the settlement from the winds of accumulated change. Daisy died, but the residents were saved.

So begin the marvels of Homo sapiens. World GDP per capita, however, would remain stagnant for another few millennia. ${ }^{98}$ Very slow and gradual indeed, Adam Smith. What remains to be told is the tragedy of the second part, the wonder of the last 200 years.

\footnotetext{
94 See Anna Wierzbicka, Emotions across Languages and Cultures: Diversity and Universals 98 (Cambridge 1999).

Envy (X felt envy)

(a) X felt something because $\mathrm{X}$ thought something

(b) sometimes a person thinks about someone else:

(c) "something good happened to this other person

(d) it didn't happen to me

(e) this is bad

(f) I want good things like this to happen to me"

(g) when this person thinks this, this person feels something bad

(h) X felt something like this

(i) because $\mathrm{X}$ thought something like this

Anna Wierzbicka, Emotions across Languages and Cultures: Diversity and Universals 98 (Cambridge 1999).

${ }^{95}$ Ridley, The Rational Optimist at 115 (cited in note 21).

${ }^{96}$ See Robert McC Adams and Hans J. Nissen, The Uruk Countryside: The Natural Setting of Urban Societies (Chicago 1972).

${ }^{97}$ Hayek, The Fatal Conceit at 40 (cited in note 2).

98 See Deirdre N. McCloskey, Bourgeois Dignity: Why Economics Can't Explain the Modern World (Chicago 2011).
} 